Int. J. Environ. Sci. Tech.

(C) Spring 2006, Vol. 3, No. 2, pp. 141-146

\title{
Utilization and flow of energy in tropical ecosystem: A test case for two Ox-bow lakes
}

\author{
${ }^{1 *}$ S. K. Das and ${ }^{2}$ D. Chakrabarty \\ ${ }^{1}$ Environmental Science Department, Netaji Subhas Open University, Wood Burn Park, India \\ ${ }^{2}$ Department of Zoology, Krishnagar Govt. College, Krishnagar, Nadia, India
}

Received 29 September 2005;

revised 15 January 2006;

accepted 7 March 2006;

available online 20 April 2006

\begin{abstract}
ABSTRAC T: To estimate the rate of organic production, two solar powered tropical natural aquatic systems (Oxbow lakes) have been studied for 24 months. The study of utilization of energy in those two tropical lakes has revealed that herbivores were more efficient in energy utilization than autotrophs. Silver carp and grass carp were found to be most efficient in conversion of energy in the grazing and detritus food chain of these lakes. The efficiency of the system to fish production was found to be $0.05 \%$ of the total available solar radiation. Various forms of life are all accompanied by energy changes, even though no energy is created or destroyed in the studied system.
\end{abstract}

Key words: Energy budget, tropical ecosystem, polyculture, Ox-bow lake, pyramid of number, pyramid of biomass

*Corresponding Author, E-mail: das_sanjibm@yahoo.com

\section{INTRODUCTION}

A central issue in the diversity-stability debate during the last several decades of community ecology and biodiversity research has been the theory that increases in community complexity decrease ecological stability (May, 1972; McCann, 2000). Notwithstanding positive complexity-stability relationships under specific model conditions (Angelis, 1975), population persistence in large and complex natural food webs remains a long-standing dilemma in ecology. To overcome this dilemma the measurement of utilization of energy and its flow in a ecosystem is important because of its usefulness for a complete evaluation of community structure in an ecosystem. Studies on the fate of energy beyond the producer level lentic system of tropics are meagre. Moreover, extensive studies have been made for temperate water bodies which could not be extrapolated to tropical systems, as they basically differ in terms of complexity of environmental factors. We report here the flow and pattern of energy utilization in two tropical ecosystems where polyculture of fishes is practiced with the inherent fishes of these lakes. The aim of our paper to study natural ecosystem in an attempt to design more energy efficient human built system (Odum, 2005).

\section{MATERIALS AND METHODS}

Two selected ox-bow lakes Hansadanga Beel (HB, 41.47 ha) and Kalinga Beel (K-B, 33.10 ha) of water area are located in a both the site investigated are situated near the tropic of cancer situated at longitude $88^{\circ} 33^{\prime} \mathrm{E}$, latitude $23^{\circ} 24^{\prime} \mathrm{N}$, of West Bengal, an eastern province of India and have been studied for 24 months, were farmed by a polyculture system with six species combination (Catla catla, Labeo rohita, Cirrhinus mrigala, Cyprinus carpio, Hypophthalmichthys molitrix and Ctenopharyngodon idella) at a ratio of 2:6:3:3:4:2, respectively. The lakes were not subjected to any application of manures. The average standing crop of number and dry weight of all trophic members (phytoplankton, zooplankton, benthic invertebrates and fishes) was used to compute the food pyramids. For construction of energy flow model and annual energy budgets, the parameters analyzed were solar radiation, gross and net primary productivity of phytoplankton (Winberg, 1963; Wetzel, 2004), photosynthetic efficiency, biomass of nanoplankton, megaplankton and total plankton (Winberg, 1971), energy contents of zooplankton, benthic invertebrates and fish (Natarajan and Pathak, 1983). The results of measurements of primary productivity, biomass of 
plankton in these two lakes is being regularly done in a practiced manner. The total production of all the inherent fishes of the lake was not considered to compute the scientific data because they were less than $2 \%$ of the total production. The dry weight of zooplankton was converted into calorific value by using the conversion factor of 5.5 (Slobodkin and Richman, 1961). An average turn over rate of 50 for zooplankton (Meshkova, 1952), (Murugan and Sivaramakrishnan, 1976) and 3 for benthic invertebrates were used to calculate their rates of annual production. The data of two annual cycles (November, 2002 to October, 2004) were pooled for annual energy budgets in the present investigation.

\section{RESULTS}

\section{Standing crop structure}

Analysis of dry weight of different components of plankton revealed that phytoplankton was the major contributor sharing $<49 \%$ of the dry weight of phytoplankton during major part of the year, whereas, zooplankton biomass contributed $<68.60 \%$ on two occasions in either lakes. The dry weight of total phytoplankton varied between 229.61 and 136125.53 $\mathrm{mg} / \mathrm{m}^{3}$ whereas that of zooplankton ranged from 88.98 to $10391.41 \mathrm{mg} / \mathrm{m}^{3}$ in two stocking lakes. The average dry weight of total plankton ranged from 2108.225 to $113447.23 \mathrm{mg} / \mathrm{m}^{3}$ and from 1597.498 to $136846.35 \mathrm{mg} /$ $\mathrm{m}^{3}$ in stocking lakes $\mathrm{H}-\mathrm{B}$ and $\mathrm{K}-\mathrm{B}$, respectively. The dry weight of benthic invertebrates varied between 1247.4616 and $10483.648 \mathrm{mg} / \mathrm{m}^{3}$ and between 1149.1558 and $9022.3308 \mathrm{mg} / \mathrm{m}^{3}$ in $\mathrm{H}-\mathrm{B}$ and K-B, respectively. The monthly mean dry weight was considerably higher in first year as compared to the second year.

\section{Food chain analysis}

The principal food chain involved in these fish lakes (Fig. 1) was broadly divided into grazing food chain and detritus food chain though the interaction between them was well marked. The primary producers of these fish lakes were represented by as many 24 genera of phytoplankton in H-B and 19 genera in K-B. Besides, some occasional aquatic macrophytes (Pistia sp., Lemna sp., Eichhornia sp.and Wolffia sp.) also contributed to some extent in the energy input of lake ecosystems. The major primary consumers were represented by different groups of herbivorous zooplankton and silver carp. There were 13 genera of zooplankton in $\mathrm{H}-\mathrm{B}$ and 10 in K-B. A considerable number of benthic algae and periphyton occurring in bottom of the fish lakes might form a source of food for benthic invertebrates including chironomid population. Catla catla with a dominant zooplankton feeding habitat (Jhingran, 1988) was an important secondary consumer in these fish ponds. Though Labeo rohita is often known to be a column feeder (Jhingran, 1988), it becomes a detritus feeder in shallow water fish lakes and thus competing to a large extent with Cirrhinus mrigala and common carp (Natarajan et al., 1975). The investigated lakes were extremely shallow with an average water depth of $1 \mathrm{~m}$. Labeo rohita stocked in these fish lakes was thus considered to be a detritus feeder. In the detritus food chain of the investigated fish lakes, Cirrhinus mrigala and Labeo rohita were found to be principal consumers of detritus and organic matter present in the bottom of the lakes. Five members of benthic invertebrates (oligochaete worms, ostracods and the larvae of Chaoborus, chironomid and culicoid) were principal consumers in the detritus food chain. According to (Kaszak and Ranke-Rybicka, 1970) and (Parma, 1971), Chaoborus consumes benthic invertebrates, plankton and organic detritus in the system. The role of common carp in these lakes was somewhat complex as it was an omnivore consuming all kinds of food available in the detritus food chain as well as zooplankton.

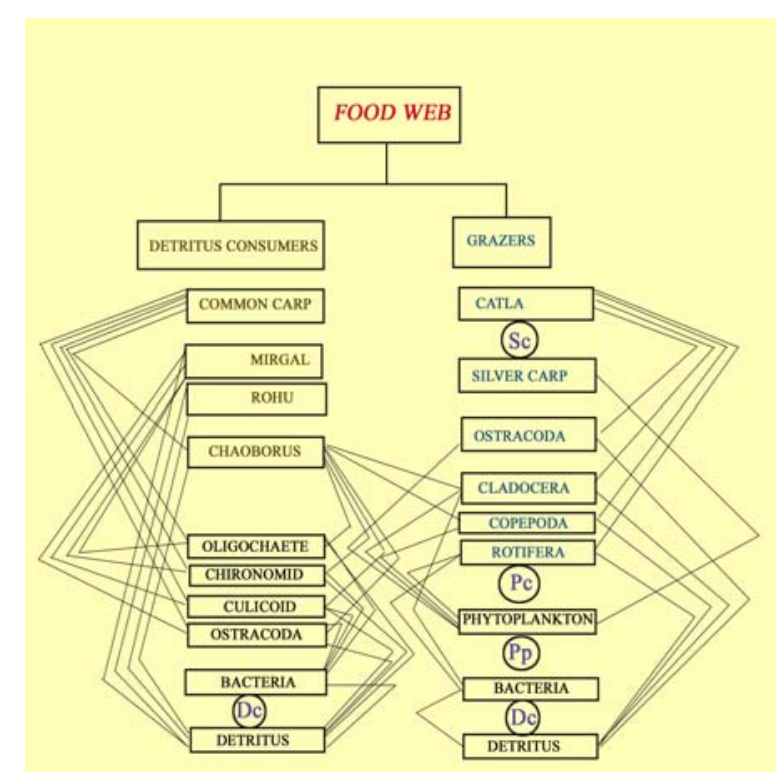

Fig. 1: Food web structure in two ox-bow lakes. (Dc=detritus consumers, $\mathrm{Pp}=$ primary producers, $\mathrm{Pc}=$ Primary consumers, Sc $=$ Secondary consumers). 


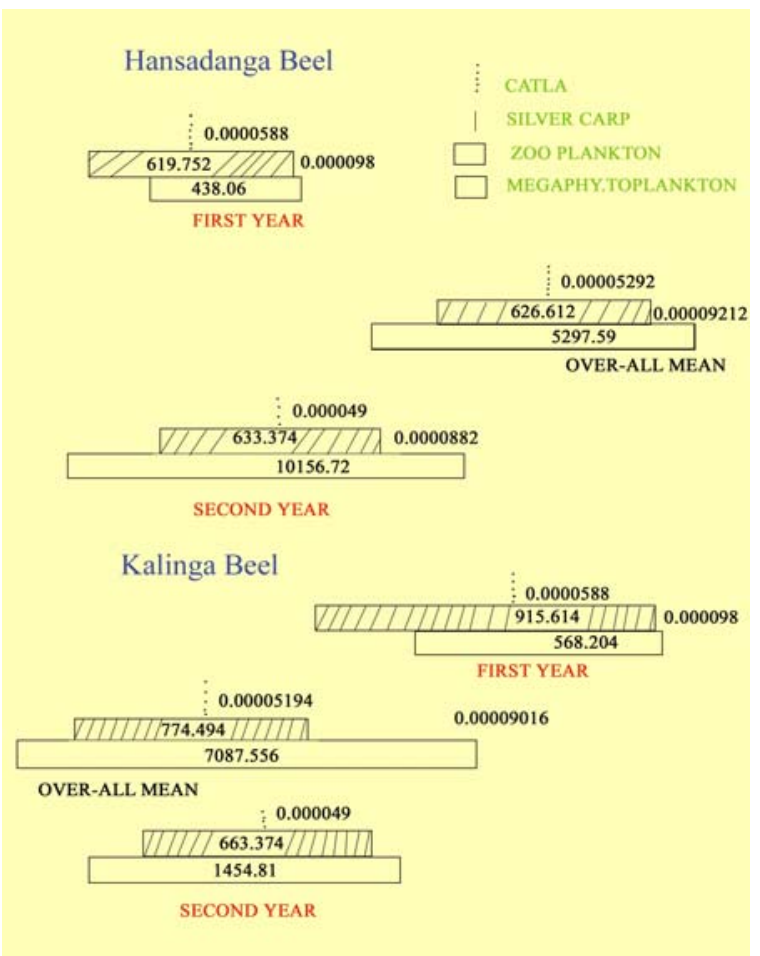

Fig. 2: Pyramid of numbers of plankton $\mathrm{x} 10 / \mathrm{h}$ in two ox-bow lakes

\section{Pyramid of numbers}

The pyramid of number arranged by trophic levels (Fig. 2) showed somewhat a inverted structure with about 1.47 times larger population of zooplankton than phytoplankton during the first year. A sloping pyramid with incorporation of about 4.4982 to $6.1152 \%$ of phytoplankton into the zooplankton was observed during the second year. When the pooled data for two years were used, a sloping pyramid was the result for each lake. It is evident that about 10.5644 to $11.5934 \%$ of phytoplankton was incorporated into the zooplankton population of this ecosystem. When the conversion of zooplankton to catla was calculated, the conversion ratio was found to be extremely low with values ranging from $0.8232 \cdot 10^{-7}$ in $\mathrm{H}-\mathrm{B}$ to $0.6566 \cdot 10^{-7}$ in K-B.

\section{Pyramid of biomass}

The structure of biomass pyramid from phytoplankton to zooplankton was found to be a sloping one in two lakes (Fig. 3). The pooled data of conversion from phyto- to zooplankton was around $11.76 \%$ in each lake. The relation between phytoplankton to silver carp

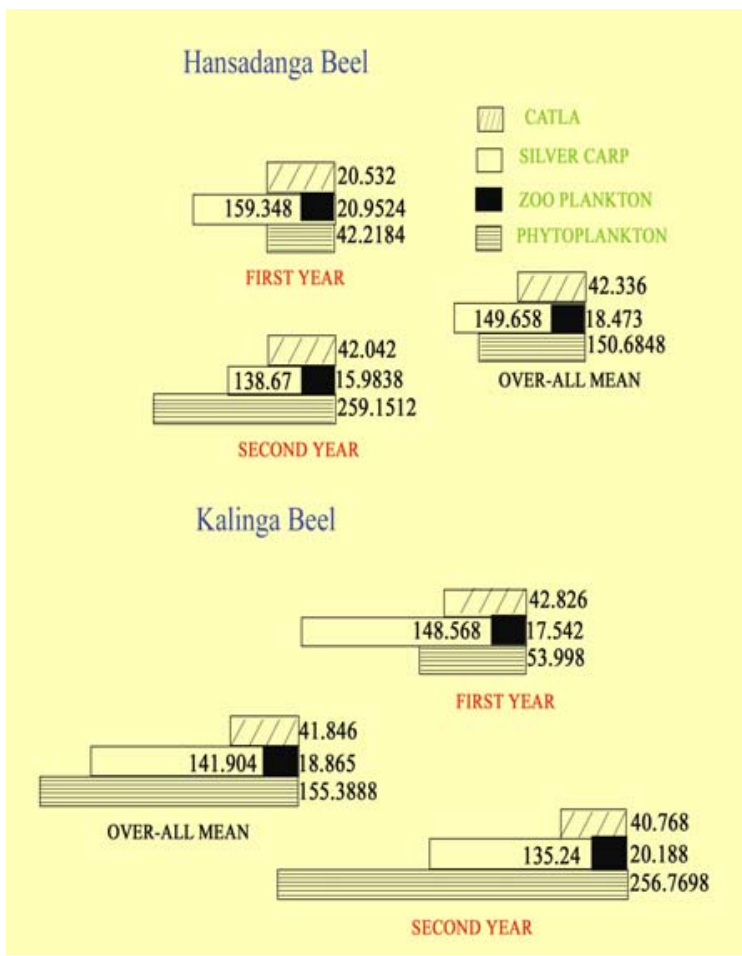

Fig. 3: Pyramid of biomass (dry weight) of plankton (kg/ha) in two ox-bow lakes

and between zooplankton to catla was, however, found to be inverted. The relationship between bottom biota and detriovorous fishes was inverted. This suggests that the benthic invertebrates were not the only source of food to the detritovorous fishes but also consumed organic detritus accumulated in the sediment of fish lakes.

\section{Autochthonous energy}

The available solar energy entering the lake system was estimated to be $70109.2 \cdot 10^{5} \mathrm{kcal} / \mathrm{ha} / \mathrm{yr}$. The values of GPP were $830.1188 \cdot 10^{5} \mathrm{kcal} / \mathrm{ha} / \mathrm{yr}$ for H-B (Fig. 4) and $895.0046 \cdot 10^{5} \mathrm{kcal} / \mathrm{ha} / \mathrm{yr}$ for K-B (Fig. 5). The photosynthetic efficiency ranged from 1.1564 to 1.2544 $\%$ in these two lakes. Hence, the NPP amounted to be $0.735 \%$ of the solar radiation in $\mathrm{H}-\mathrm{B}$ and $0.8624 \%$ in $\mathrm{K}$ $B$. In the grazing food chain, the herbivore production through zooplankton in two lakes was 5.9976 and 5.684 $\%$ of the GPP and 9.4178 and $8.2124 \%$ of the NPP, respectively. At the top of grazing food chain, the production of catla through zooplankton did not differ between H-B and K-B (6.37 \%). The food conversion efficiency from phytoplankton to catla (0.3724 to 
$0.4018 \%$ ) was less than that of silver carp. In detritus food chain of the investigated lakes, the production of the benthic invertebrates ranged from $6.7816 \cdot 10^{5}$ to $6.9384 \cdot 10^{5} \mathrm{kcal} / \mathrm{ha} / \mathrm{yr}$. In two lakes, the production of the various benthivorous fishes was: Labeo rohita - $6.664 \cdot 10^{5} \mathrm{kcal} / \mathrm{ha} / \mathrm{yr}$; Cirrhinus mrigala -2.793 to $2.8518 \cdot 10^{5} \mathrm{kcal} / \mathrm{ha} / \mathrm{yr}$ and Cyprinus carpio -8.4378 to $9.0356 \cdot 10^{5} \mathrm{kcal} / \mathrm{ha} / \mathrm{yr}$. The conversion efficiency from GPP to benthivorous fishes ranged from 0.3038 to $0.3332 \%$ for Cirrhinus mrigala, 0.7252 to $0.784 \%$ for Labeo rohita and 0.9212 to $1.0682 \%$ for common carp. The energy output in these lake system amounted to be 3.8416 to $4.312 \%$ and 5.5566 to 6.8208 $\%$ of the gross and net primary production, respectively. The efficiency of the system to fish production was found to be $0.049 \%$ of the total available solar radiation.

\section{Allochthonous energy}

The input of energy added macrophytes (Hydrilla sp.) as feed for grass carp was $140.0028 \cdot 10^{5} \mathrm{kcal} / \mathrm{ha} / \mathrm{yr}$. The energy output of grass carp at the time of harvest was $6.7228 \cdot 10^{5} \mathrm{kcal} / \mathrm{ha} / \mathrm{yr}$ for H-B and $6.2818 \cdot 10^{5} \mathrm{kcal} / \mathrm{ha} / \mathrm{yr}$ for K-B with a conversion efficiency of 4.4002 to $4.704 \%$.

\section{Energy utilization in the system}

Of the total energy output through fish yield, primary consumers contributed as much as $90.013 \%$ (K-B) to
$90.258 \%$ (H-B), whereas the contribution by secondary consumers was between $7.742 \%$ (H-B) and $7.987 \%$ (KB). The ratio of energy utilization between primary consumer and secondary consumer is marginally higher $(<0.38 \%)$ in H-B rather than K-B. The energy utilized through primary consumption ranged from 75.0288 to $75.1268 \%$ through autochthonous source and 14.8862 to $15.2292 \%$ through allochthonous source (Table 1). Again the energy utilized through grazing and detritus food chain of the autochthonous source was estimated to be 32.34 and $42.14 \%$, respectively.

\section{DISCUSSION AND CONCLUSION}

The magnitude of energy fixed by producers in these managed farm lakes appeared to be higher than those reported for unmanaged tropical impoundments (Ganapati and Sreenivasan, 1972), (Pathak et al., 1985), (Natarajan and Pathak, 1983) or temperate water bodies (Lindeman, 1942). Since the efficiency of assimilation of conversion tended to rise at higher trophic level despite with less amount of available energy at each trophic level, it shows that herbivores were more efficient in food conversion than the autotrophs. Of all the species of carp in the grazing food chain, silver carp showed about 4 fold rise in energy output from gross production compared with catla (0.3724 and $0.4018 \%$ ), while amongst the species of detritus food chain, the conversion efficiency was maximum for common carp

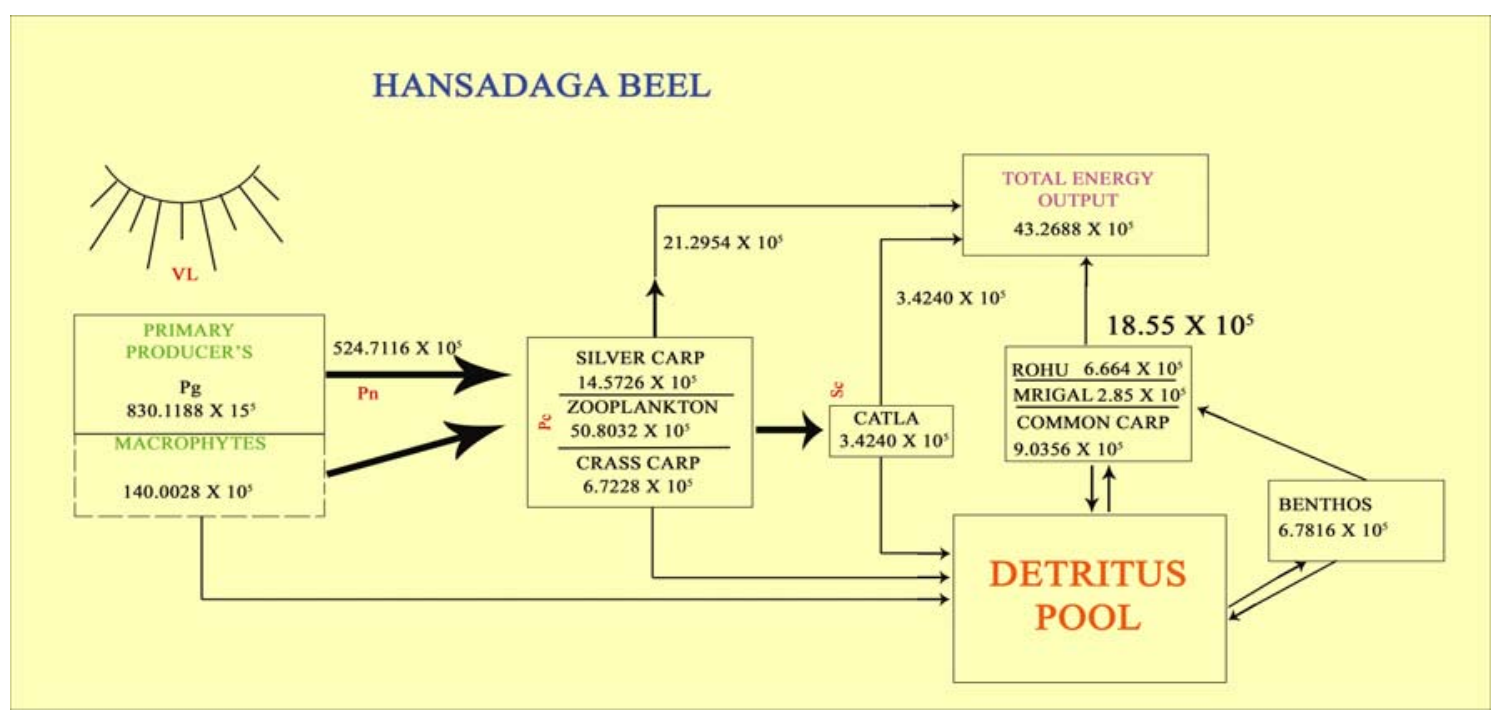

Fig. 4: Conceptual energy flow diagram for Hansadaga beel, in $\mathrm{Kcl} / \mathrm{h} / \mathrm{y}\left(\mathrm{V}=\right.$ visible light nergy; $\quad \mathrm{P}_{\mathrm{g}}=$ gross primary production; $\mathrm{P}_{\mathrm{n}}=$ net primary production; $\mathrm{P}_{\mathrm{c}}=$ primary consumers; $\mathrm{S}_{\mathrm{c}}=$ secondary consumers; $\mathrm{D}_{\mathrm{c}}=$ Detrirus consumers 
Utilization and flow...

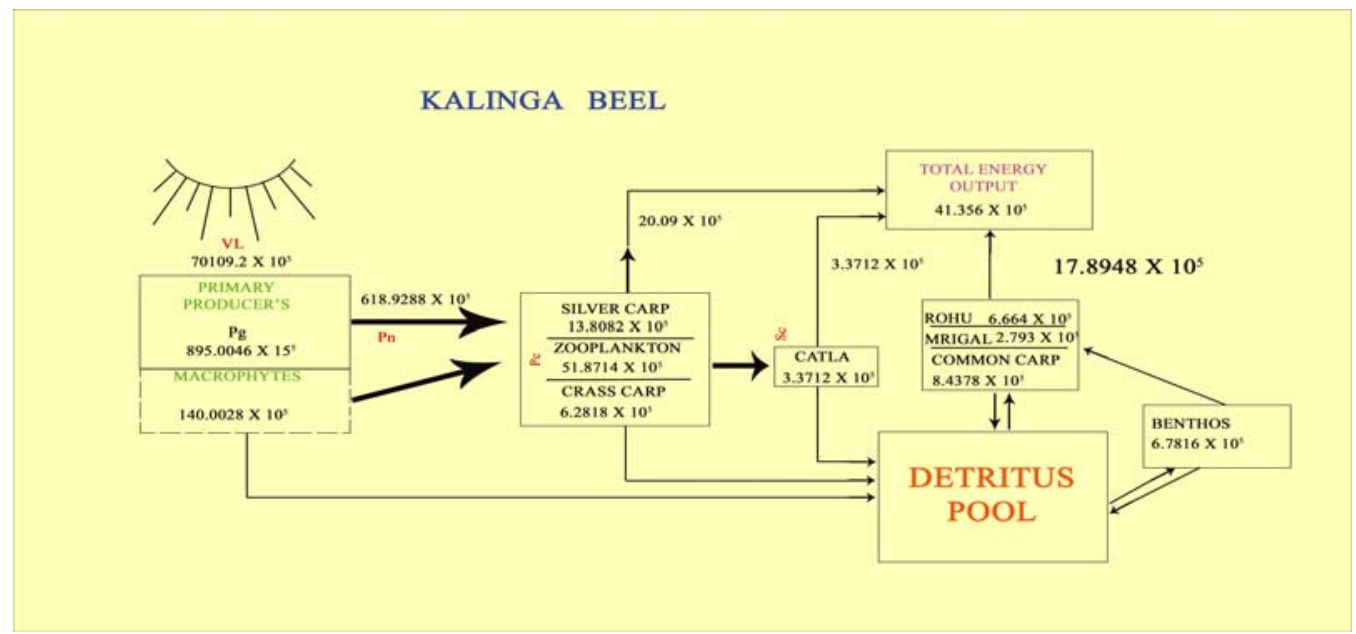

Fig. 4: Conceptual energy flow diagram for Kalinga Beel, in Kcl/h/y (V= visible light energy;

$\mathrm{P}_{\mathrm{g}}=$ gross primary production; $\mathrm{P}_{\mathrm{n}}=$ net primary production; $\mathrm{P}_{\mathrm{c}}=$ primary consumers; $\mathrm{S}_{\mathrm{c}}=$ secondary consumers; $\mathrm{D}_{\mathrm{c}}=$ Detrirus consumers

Table 1: Energy utilization through various food chains and pathways in two Ox- bow lakes

\begin{tabular}{|c|c|c|c|c|c|c|c|c|}
\hline \multirow{3}{*}{$\begin{array}{c}\text { Ox-bow } \\
\text { lakes }\end{array}$} & \multicolumn{4}{|c|}{$\begin{array}{l}\text { Primary consumption } \\
\text { Autochthonous source }\end{array}$} & \multicolumn{4}{|c|}{$\begin{array}{l}\text { Secondary consumption } \\
\text { Allochthonous }\end{array}$} \\
\hline & \multirow[b]{2}{*}{$\mathrm{Kcal} / \mathrm{ha} / \mathrm{yr}$} & \multicolumn{3}{|c|}{ Through grazing chain } & \multicolumn{2}{|c|}{ Through detritus chain } & \multirow[b]{2}{*}{$\mathrm{Kcal} / \mathrm{ha} / \mathrm{yr}$} & \multirow[b]{2}{*}{$\%$} \\
\hline & & $\%$ & $\mathrm{Kcal} / \mathrm{ha} / \mathrm{yr}$ & $\%$ & $\mathrm{Kcal} / \mathrm{ha} / \mathrm{yr}$ & $\%$ & & \\
\hline $\begin{array}{c}\text { Hansadanga } \\
\text { beel }\end{array}$ & 14.5726 & 33.0064 & 18.5514 & 42.0224 & 6.7228 & 15.2292 & 15.2292 & 7.742 \\
\hline $\begin{array}{c}\text { Kalinga } \\
\text { beel }\end{array}$ & 13.8082 & 31.7422 & 17.8948 & 42.4046 & 6.2818 & 14.8862 & 3.3712 & 7.987 \\
\hline
\end{tabular}

(0.9212 and $9.8 \%$ ) and minimum for Cirrhinus mrigala (0.3038 and $0.3332 \%)$. Thus, silver carp and common carp were the most efficient converters of energy in the grazing and detritus food chains of the lake, respectively. Though the supplied energy to grass carp through added macrophytes was in net form and the energy supplied to other fish through phytoplankton was in gross form, the import of energy through net primary production of phytoplankton (autochthonous source) was 3.675 to 4.3316 times higher than that of added macrophytes (allochthonous source). Because the conversion efficiency of grass carp from macrophytes (4.4002 and $4.704 \%$ ) was about 2.45 to 13.72 folds higher than those of other test fishes, it appears that grass carp was the best utilizer of food resources among all the species of fish cultured. It is evident that greater production of energy was not utilized and remained in the system as standing crop. It is obvious, then, that much more energy was potentially available for the cultured fishes than was actually consumed. It is possible that stocking density of fish might be increased with existing food resources without any growth compensation of carp for a sustainable yield as the important efficiency is related to exploitation efficiency, assimilation efficiency and production efficiency (Chapman and Reiss, 2005). Stocking densities of silver carp and common carp may be raised up to 1.5 times from stocking density. Such increase will not hamper water quality parameters and health of the stocking fishes.

\section{REFERENCES}

Chapman, J. L. and Reiss, M. J., (2005). Ecology: principles

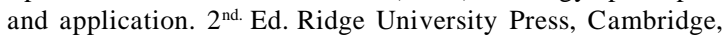
UK. 
De Angelis, D. L., (1975). Stability and connectance in food web models. Ecology, 56, 238-243.

Ganapati, S. V. and Sreenivasan, A., (1972). Energy flow in aquatic ecosystems in India. Proc. IBP Symp. Productivity problems of freshwater. Warszaw, Krakow.

Jhingran, V. G., (1988). Fish and Fisheries of India. - Second ed. Hindustan Publishing Corporation, New Delhi, 666.

Kaszak, Z. and Ranke-Rybicka, B., (1970). Feeding and production efficiency of Chaoborus flavicans Meigen (Diptera, Culicidae) larvae in eutrophic and dystrophic lakes. Poll. Arch. Hydrobio., 17, 225-232.

Lindeman, R. L. (1942). The trophic dynamic aspects of ecology. Ecology, 23, 398-418.

May, M., (1972). Will a large complex system be stable? Nature, 238, 413-414.

Mc Cann, K., (2000). The diversity-stability debate. Nature, 405, 228-233.

Meshkova, T. M., (1952). Zooplankton ozera Sevan (biologiya i produktivnost'). Trudy Sevan Gidrobiol. Sta., 13, 5-170.

Murugan, N. and Sivaramakrishnan, K. G., (1976). Laboratory studies on the longevity, instar duration, growth, reproduction and embryonic development in Scapholeberis kingi SARS (1903) (Cladocera: Daphnidae). J. Hydrobio., 50, 75-80.
Natarajan, A. V., Ramakrishnaiah, M. and Khan, M. A., (1975). The food spectrum of trash fishes in relation to major carps in Konar and Tilaiya reservoirs (Bihar). J. Inland Fish. Soc., India, 7, 65-75.

Natarajan, A. V. and Pathak, V., (1983). Pattern of energy flow in freshwater tropical and subtropical impoundments. - Bull. 36, Central Inland Fisheries Research Institute (ICAR), Barrackpore, West Bengal, India, 1-27.

Odum, E. P. and Barrett, G. W., (2005). Fundamentals of Ecology. Fifth Edition. E W P. Thomson/ Brooks/cde.

Parma, S., (1971). Chaoborus flavicans (Meigen) (Diptera, Chaoboridae): An ecological study. Ph.D. Diss. Groningen, the Netherlands, 128.

Pathak, V., Saha, S. B. and Bhagat, M. J., (1985). Patterns of energy utilization and productivity in beel ecosystems. J. Hydrobio., 1, 47-52.

Slobodkin, L. B. and Richman, S., (1961). Calories $g^{-1}$ in species of animals. Nature, 191, 299.

Wetzel, R. G. and Likens, G. E., (2004). Limnological Analysis. $3^{\text {rd. }}$ Ed. Springer International Edition.

Winberg, G. G., (1963). Primary production of bodies of water,U. S. Atom Energ. Comm. Div. Tech. Info. AEC, 5692 .

Winberg, G. G., (1971), Methods for the Estimation of Production of Aquatic Animals. Academic Press, London and New York, 175.

\section{AUTHOR(S) BIOSKETCHES}

Das, S. K., M.Sc. (Ecology and Environment), Research scholar, Department of Environmental Science, Netaji Subhas Open University, 1, Wood Burn Park, Kolkata-700020, India,

E-mail:_das_sanjibm@yahoo.com.

Chakrabarty, D., Ph.D,WBES (West Bengal Education Service), Reader and head, Department of Zoology, Krishnagar Govt. College, Krishnagar-741101, Nadia, India.

E-mail:_debajyoti_chakrabarty@yahoo.com

\section{This article should be referenced as follows:}

Das, S. K. and Chakrabarty, D., (2006). Utilization and flow of energy in tropical ecosystem: A test case for two Ox-bow lakes. Int. J. Environ. Sci. Tech., 3 (2), 141-146. 